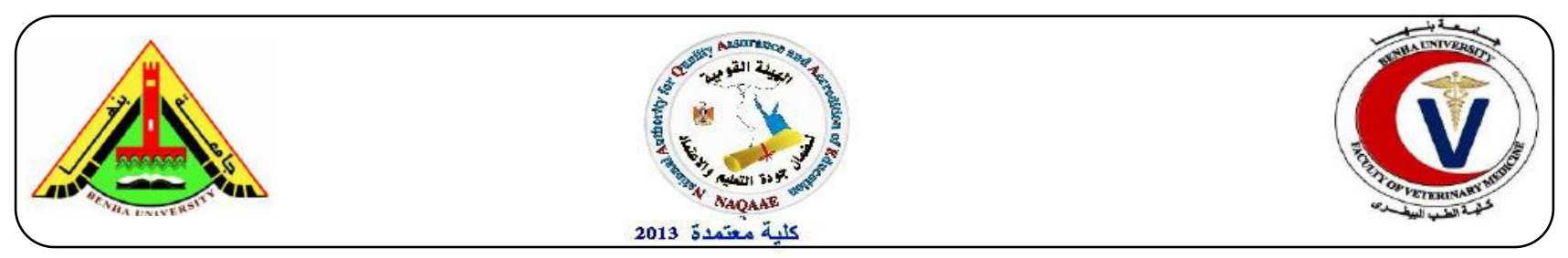

\title{
Concurrent Use of Tilmicosine and Thyme Oil in Treatment of Mycoplasma gallisepticum in Chickens
}

${ }^{1}$ Elsayed A. Abdel-aziz, ${ }^{1}$ Sawsan M. ${ }^{1}$ El-Shaikh, Emam, E. E. and 2Nasralla, A.H.E.

${ }^{1}$ Pharmacology Dept., Faculty of Veterinary Medicine, Zgazig University, Egypt.

${ }^{2}$ Animal Health Research Institute, Egypt.

\section{A B S T R A C T}

The objective of this study is designed to clarify the effect of tilmicosin and thyme oil on treatment of chronic respiratory disease in broiler chickens. Eighty one-day old chicks tested negative Mycoplasma gallisepticum (MG). On the $22^{\text {th }}$ day of age the chicks were divided into five equal groups Gp. (1) non infected non treated ( control ), but chicks in Gp. (2, 3, 4, and 5) at $22^{\text {th }}$ day of age were inoculated with $0.2 \mathrm{ml}$ of MG broth into air sac. Gp (1) non infected non treated ( control), Gp.(2) infected non treated, Gp.(3) infected treated with thyme oil 200 ppm for 5 successive days, Gp.(4) infected treated with tilmicosin $25 \mathrm{mgkg}$ for 5 successive days. and Gp.(5) infected treated with both thyme oil and tilmicosin in same dose and period. At $1^{\text {st }}$ and $7^{\text {th }}$ day post treatment all chicks in all groups were weighed and blood samples were collected for hematobiochemical studies, biochemical studies and phagocytic activity. The clinical signs observed in infected broilers chickens were poor appetite, depression, nasal discharge, mild conjunctivitis, sneezing, coughing, gasping, rales and mortalities were 20\%. Our results revealed that infected non treated chicks showed significant decrease in body weight gain, RBCs, Hb, PCV, WBCs, T.Protein, albumin and globuln beside significant increase in AST, ALT, creatinine, uric acid, phagocytic activity and phagocytic index at $1^{\text {st }}$ day post treatment. Treated infected broilers chickens with tilmicosin and thyme oil showed improvements in clinical signs, mortalities and body weight beside improvement in hematobiochemical and biochemical parameters and phagocytic activity post treatment. The pathological examination of internal organs of $\mathrm{MG}$ infected broiler chickens showed severe pathological lesions in lung, liver, kidney and heart. But infected broiler chickens treated with both thyme oil and tilmicosin is induced marked improvement in the pathological changes. It could be concluded that the concurrent use of both thyme oil and tilmicosin is a useful mean to treat and control CRD in broiler chicks. Thyme oil can be used as an assistant factor to retard CRD in broiler chicks due to its immune enhancer and growth promoter properties.

Keywords: Tilmicosine and Thyme Oil, Mycoplasma gallisepticum, Chickens.

(http://www.bvmj.bu.edu.eg)

(BVMJ-35(1): 236-249, 2018)

\section{INTRODUCTION}

In the poultry industry, it is important to stimulate the immune system to decrease or prevent infectious diseases. Numerous factors like inhibition of antibiotics and failure of vaccination can induce immunodeficiency.
The usage of immune enhancers is a key solution to improve immunity and reduce susceptibility to infectious diseases in poultry farms. Phytogenic feed additives, which are rich in flavonoids, extend the biological activity of ascorbic acid, act as antioxidants 
and may enhance immune function (Acamovic and Brooker, 2005). Thymol, carvacrol and 6-gingerol possess useful antioxidant properties and may become important in the search for 'natural' replacements for synthetic antioxidant food additives (Aeschbach $\mathrm{R}$ et al, 1994). Thyme methanol extract possessed the best antioxidative activity (Mohamed et al, 2013).

Thyme oil induces significant increase in total proteins and globulins (Xiaolei Zhu et. al, 2014). Thyme oil for broiler chicks improves the growth and performance (Saki et. al., 2014). Thyme oil improves antioxidant status and enhancing an immune response in chickens (Placha et al., 2014 and Placha et al., (2013).

Mycoplasma gallisepticum continuous to be of primary concern to the poultry industry worldwide as it commonly affects intensively reared chickens and turkeys causes large economic losses (Evans et al., 2002). Mycoplasma gallisepticum is a major pathogen species in poultry which causes chronic respiratory disease in chickens. Economic losses in the poultry industry caused by Mycoplasma gallisepticum (Stipkovits and Kempf, 1996). Uncomplicated cases of MG infection don't always cause overt clinical signs or mortality, but can result in sub-optimum production, unacceptable feed conversion ratio and down grading of the carcasses (Charleston et al., 1998).

Tilmicosin is a semisynthetic, broad spectrum, bacteriostatic macrolide antibiotic synthesized from tylosin for veterinary uses (Kempf et al. 1997). Tilmicosin offers promising prospect of application in clinical veterinary practices. It is a useful drug for treatment and control of respiratory diseases due to its high volume of distribution, long half-life and preferable accumulation in lung. Tilmicosin is used for control and treatment of respiratory diseases caused by Mycoplasma spp (Jordan \& Horrocks 1996, Abu-Basha et al. 2007). Chicken must not be slaughtered before 4 days from the stopping of tilmicosin administration (Mossad Elsayed et. al, 2014).

This work focused on the study of the efficacy of thyme oil and tilmicosin either alone or together in treatment CRD infected broiler chickens and studying there effects on clinical symptoms, mortalities, body weight and hematobiochemical parameters.

\section{MATERIALS AND METHODS}

Drugs:

1-Tilmicosin: Tilmicosin phosphate was obtained as an oral solution from ATCO Pharma for Pharmaceutical Industries, Cairo, Egypt under a trade name tilmicoral ${ }^{\circledR}$, a $25 \%$ oral solution.

2- Thyme oil: Dry thyme plant is obtained from the local market in Ismailia city, Egypt. Using ethanol $75 \%$ as solvent then freeze drying process according (Vamanu Emanuel et. al 2011).

- The dose of thyme oil was used in drinking water equivalent to $200 \mathrm{ppm}$ of feed intake (Adel Feizi et al., 2013; Al-Kassie, 2009 and Mahmoodi, 2014).

Experimental birds:

Eighty one-day old apparently healthy chicks (Arbor-Acres) sourced from tanbul For Investment \& Poultry Company; five chicks randomly selected, humanly euthanized and tested negative MG by using PCR test. Chicks were fed on commercial unmedicated balanced ration. Chicks were housed under hygienic conditions, feed and water provided ad libtum .

Mycoplasma gallisepticum challenge

Mycoplasma gallisepticum strain that used in this study was obtained from Animal Health Research Institute, El-Dokki, Giza On day 22 of age, 60 experimental infection via air sacs inoculation with $0.2 \mathrm{ml}$ (10 8 C.F.U.) according to (Ellakany et al., 1997).

\section{Experimental design:}


into 5 equal groups each of (15) in separated units, $1^{\text {st }} \mathrm{Gp}$ was served as control (non infected non treated), the $2^{\text {nd }} \mathrm{Gp}$ infected non treated, $3^{\text {rd }} \mathrm{Gp}$ infected treated with $200 \mathrm{ppm}$ thyme oil in drinking water for 12 hours (equivalent to $200 \mathrm{ppm}$ in feed for 24 hours). $4^{\text {th }} \mathrm{Gp}$ were infected treated with tilmicosin $25 \mathrm{mg} / \mathrm{kg}$. B.wt for 8 hours for 5 successive days, and $5^{\text {th }} \mathrm{Gp}$ were infected treated with thyme oil and tilmicosin in same dose and period Clinical findings, mortalities, were recorded also.

Performance parameters.

Broiler chickens were weighted at $22^{\text {nd }}$ day of age and at $1^{\text {st }}$ and $7^{\text {th }}$ day post treatment, feed consumption and weight gain were recorded and feed conversion rate was calculated.

Blood samples

At $1^{\text {st }}$ and $7^{\text {th }}$ day post treatment five chicks from all $g$ complete blood picture determination by using automated blood cell analyzer (Sysmex XT2000iV, Kobe, Japan) (Harvey, 2012).
Dray swabs from theses organ were dipped several times in Frey's broth and incubated at $37^{\circ} \mathrm{C}$ (until the color become yellow). By sterile Pasteur pipette $1 \mathrm{ml}$ of the suspension was spread on the surface of the petri-dish plate contain Frey's media(mycoplasma Selective Agar media), the suspension was spread in different directions using a platinum loop to wet the whole of its surface and excessive fluid was discarded.

Histopathological examination:

Post chick slaughtered specimens from the lungs, liver, kidneys and heart were collected and fixed in $10 \%$ neutral buffered formalin solution. Five-micron thick paraffin sections were prepared and stained by hematoxylin and eosin (H\&E.) according to (Bancroft and Stevens 1996).

Statistical analysis:

The third blood samples were taken to obtain clear serum and estimation of AST and ALT according to R according to results of albumin (Artiss 1981).

Cereatinine (Henary, 1974).

Bacteriological examination:

At $9^{\text {th }}$ day post infection trachea, lung and air sac were collected for isolation of MG.

Table (1): Effect of tilmicosin (25 mg / kg BW) and or / thyme oil (200 ppm ) each alone and their combination given for 5 successive days on productive performance in treatment of MG- infected broiler chickens. (Mean \pm S.E) $\quad \mathrm{n}=5$.

\begin{tabular}{|c|c|c|c|c|c|c|c|c|}
\hline \multirow[t]{2}{*}{ Group } & \multicolumn{3}{|c|}{ Mortality } & initial Body & weight & \multicolumn{2}{|c|}{ Weight post treatment } & \multirow[t]{2}{*}{ FCR } \\
\hline & No & No & $\%$ & (on $22^{\text {nd }}$ day) & & $1^{\text {st }}$ day & $7^{\text {th }}$ day & \\
\hline $\mathrm{GP}(1)$ & 15 & 0 & 0 & $0.635 \pm 0.01^{\mathrm{a}}$ & & $1.538 \pm 0.02^{\mathrm{a}}$ & $2.111 \pm 0.06^{\mathrm{a}}$ & 2.00 \\
\hline $\mathrm{GP}(2)$ & 15 & 3 & 20 & $0.613 \pm 0.01^{\mathrm{a}}$ & & $1.300 \pm 0.02^{b}$ & $1.399 \pm 0.02^{\mathrm{d}}$ & 2.67 \\
\hline $\mathrm{GP}(3)$ & 15 & 2 & 13.3 & $0.615 \pm 0.01^{\mathrm{a}}$ & & $1.485 \pm 0.05^{\mathrm{a}}$ & $1.795 \pm 0.03^{c}$ & 2.30 \\
\hline $\mathrm{GP}(4)$ & 15 & 1 & 6.6 & $0.612 \pm 0.01^{\mathrm{a}}$ & & $1.500 \pm 0.03^{\mathrm{a}}$ & $1.948 \pm 0.04^{b}$ & 2.15 \\
\hline $\mathrm{GP}(5)$ & 15 & 1 & 6.6 & $0.618 \pm 0.01^{\mathrm{a}}$ & & $1.510 \pm 0.03^{\mathrm{a}}$ & $1.979 \pm 0.03^{b}$ & 2.13 \\
\hline
\end{tabular}

Means within same column carrying different superscripts are significantly different at $(\mathrm{P}<0.05)$. 
Table (2): Effect of tilmicosin (25 mg / $\mathrm{kg} \mathrm{BW)} \mathrm{and} \mathrm{or} \mathrm{/} \mathrm{thyme} \mathrm{oil} \mathrm{(200} \mathrm{ppm} \mathrm{)} \mathrm{each} \mathrm{alone} \mathrm{and} \mathrm{their}$ combination given for 5 successive days on some hematological parameters in treatment of MG- infected broiler chickens.(Mean \pm S.E) $n=5$.

\begin{tabular}{lllllll}
\hline Parameters & GP $(1)$ & GP $(2)$ & GP(3) & GP(4) & GP(5) \\
RBCs & $1^{\text {st }}$ day & $2.213 \pm 0.03^{\mathrm{b}}$ & $1.846 \pm 0.03^{\mathrm{c}}$ & $2.437 \pm 0.03^{\mathrm{a}}$ & $2.163 \pm 0.009^{\mathrm{b}}$ & $2.257 \pm 0.037^{\mathrm{b}}$ \\
$\left(10^{6} / \mathrm{ul}\right.$ & $7^{\text {th }}$ day & $2.483 \pm 031^{\mathrm{a}}$ & $2.110 \pm 0.14^{\mathrm{b}}$ & $2.116 \pm 0.03^{\mathrm{c}}$ & $2.320 \pm 0.13^{\mathrm{ab}}$ & $2.380 \pm 0.15^{\mathrm{ab}}$ \\
$\mathrm{HB}$ & $1^{\text {st }}$ day & $8.000 \pm 0.07$ & $7.133 \pm 0.07^{\mathrm{c}}$ & $9.066 \pm 0.09^{\mathrm{a}}$ & $8.266 \pm 0.27^{\mathrm{b}}$ & $8.366 \pm 0.32^{\mathrm{b}}$ \\
$(\mathrm{g} / \mathrm{dl})$ & $7^{\text {th }}$ day & $9.500 \pm 0.21$ & $8.233 \pm 0.52$ & $8.433 \pm 0.21$ & $9.400 \pm 0.56$ & $9.600 \pm 0.60$ \\
$\mathrm{PCV}$ & $1^{\text {st }}$ day & $32.466 \pm 0.44^{\mathrm{a}}$ & $27.533 \pm 1.59^{\mathrm{b}}$ & $28.100 \pm 0.10^{\mathrm{ab}}$ & $31.067 \pm 1.89^{\mathrm{ab}}$ & $31.73 \pm 1.97^{\mathrm{ab}}$ \\
$(\%)$ & $7^{\text {th }}$ day & $32.466 \pm 0.44^{\mathrm{a}}$ & $27.533 \pm 1.59^{\mathrm{b}}$ & $28.100 \pm 0.10^{\text {ab }}$ & $31.067 \pm 1.89^{\mathrm{ab}}$ & $31.73 \pm 1.97^{\mathrm{ab}}$ \\
$\mathrm{WBCs}$ & $1^{\text {st }}$ day & $13.133 \pm 0.39^{\mathrm{bc}}$ & $9.167 \pm 1.67^{\mathrm{c}}$ & $20.633 \pm 1.82^{\mathrm{a}}$ & $16.733 \pm 0.15^{\mathrm{ab}}$ & $20.433 \pm 1.77^{\mathrm{a}}$ \\
$\left(10^{3} / \mathrm{ul}\right.$ & $7^{\text {th }}$ day & $20.633 \pm 0.37$ & $13.600 \pm 3.04$ & $16.433 \pm 1.95$ & $19.800 \pm 2.31$ & $20.533 \pm 4.12$ \\
\hline
\end{tabular}

Means within same column carrying different superscripts are significantly different at $(\mathrm{P}<0.05)$.

Table (3): Effect of tilmicosin (25 mg / $\mathrm{kg} \mathrm{BW)} \mathrm{and} \mathrm{or} \mathrm{/} \mathrm{thyme} \mathrm{oil} \mathrm{(200} \mathrm{ppm} \mathrm{)} \mathrm{each} \mathrm{alone} \mathrm{and} \mathrm{their}$ combination given for 5 successive days on liver enzymes, uric acid and creatinine in treatment of MGinfected broiler chickens.(Mean \pm S.E) $n=5$.

\begin{tabular}{lllllll}
\hline Parameters & GP(1) & GP(2) & GP(3) & GP(4) & GP(5) \\
AST & $1^{\text {st }}$ day & $24.00 \pm 2.05^{\mathrm{d}}$ & $212.80 \pm 7.19^{\mathrm{a}}$ & $102.40 \pm 4.45^{\mathrm{c}}$ & $121.8 \pm 10.38^{\mathrm{b}}$ & $131.2 \pm 5.42^{\mathrm{b}}$ \\
$(\mathrm{U} / \mathrm{L})$ & $7^{\text {th }}$ day & $29.00 \pm 2.77^{\mathrm{c}}$ & $178.60 \pm 9.15^{\mathrm{a}}$ & $143.0 \pm 22.44^{\mathrm{a}}$ & $73.2 \pm 16.31^{\mathrm{bc}}$ & $126.6 \pm 21.6^{\mathrm{ab}}$ \\
ALT & $1^{\text {st }}$ day & $25.20 \pm 3.07^{\mathrm{b}}$ & $69.00 \pm 9.74^{\mathrm{a}}$ & $67.80 \pm 5.71^{\mathrm{a}}$ & $63.00 \pm 12.68^{\mathrm{a}}$ & $50.0 \pm 11.90^{\mathrm{ab}}$ \\
$(\mathrm{U} / \mathrm{L})$ & $7^{\text {th }}$ day & $26.60 \pm 3.35^{\mathrm{b}}$ & $57.00 \pm 5.79^{\mathrm{a}}$ & $43.20 \pm 5.78^{\mathrm{ab}}$ & $43.20 \pm 6.54^{\mathrm{ab}}$ & $41.80 \pm 8.61^{\mathrm{ab}}$ \\
Cratnine & $1^{\text {st }}$ day & $0.840 \pm 0.05^{\mathrm{c}}$ & $1.120 \pm 0.06^{\mathrm{a}}$ & $1.00 \pm 0.09^{\mathrm{ab}}$ & $0.95 \pm 0.05^{\mathrm{bc}}$ & $0.94 \pm 0.05^{\mathrm{bc}}$ \\
$(\mathrm{mg} / \mathrm{dL})$ & $7^{\text {th }}$ day & $0.840 \pm 0.09^{\mathrm{b}}$ & $1.224 \pm 0.19^{\mathrm{a}}$ & $0.98 \pm 0.09^{\mathrm{ab}}$ & $0.98 \pm 0.08^{\mathrm{ab}}$ & $1.04 \pm 0.07^{\mathrm{ab}}$ \\
Uric acid & $1^{\text {st }}$ day & $5.820 \pm 0.51^{\mathrm{b}}$ & $7.860 \pm 0.59^{\mathrm{a}}$ & $6.146 \pm 0.19^{\mathrm{b}}$ & $6.200 \pm 0.36^{\mathrm{b}}$ & $6.44 \pm 0.17^{\mathrm{b}}$ \\
$(\mathrm{mg} / \mathrm{dl})$ & $7^{\text {th }}$ day & $6.800 \pm 0.24^{4}$ & $7.020 \pm 0.258$ & $5.20 \pm 1.16$ & $5.84 \pm 0.35$ & $6.64 \pm 0.22$ \\
\hline
\end{tabular}

Means within same column carrying different superscripts are significantly different at $(\mathrm{P}<0.05)$.

Table (4): Effect of tilmicosin (25 mg / $\mathrm{kg} \mathrm{BW)} \mathrm{and} \mathrm{or} \mathrm{/} \mathrm{thyme} \mathrm{oil} \mathrm{(200} \mathrm{ppm} \mathrm{)} \mathrm{each} \mathrm{alone} \mathrm{and} \mathrm{their}$ combination given for 5 successive days on protein picture in treatment of MG- infected broiler chickens.(Mean \pm S.E) $n=5$.

\begin{tabular}{lllllll}
\hline Parameters & GP(1) & GP(2) & GP(3) & GP(4) & GP(5) \\
T.Protein & $1^{\text {st }}$ day & $7.460 \pm 0.08^{\mathrm{a}}$ & $6.160 \pm 0.72^{\mathrm{b}}$ & $7.160 \pm 0.12^{\mathrm{a}}$ & $7.400 \pm 0.01^{\mathrm{a}}$ & $7.36 \pm 0,10^{\mathrm{a}}$ \\
$(\mathrm{g} / \mathrm{dl})$ & $7^{\text {th }}$ day & $7.320 \pm 0.12^{\mathrm{a}}$ & $6.520 \pm 0.43^{\mathrm{b}}$ & $7.240 \pm 0.11^{\mathrm{a}}$ & $7.360 \pm 0.12^{\mathrm{a}}$ & $7.560 \pm 0.04^{\mathrm{a}}$ \\
Albumin & $1^{\text {st }}$ day & $4.220 \pm 0.07^{\mathrm{a}}$ & $3.560 \pm 0.41^{\mathrm{b}}$ & $4.020 \pm 0.15^{\mathrm{ab}}$ & $4.02 \pm 0.05^{\mathrm{ab}}$ & $4.18 \pm 0.05^{\mathrm{ab}}$ \\
$(\mathrm{g} / \mathrm{dl})$ & $7^{\text {th }}$ day & $4.220 \pm 0.11$ & $3.900 \pm 0.12$ & $4,100 \pm 0.07$ & $4.36 \pm 0.68$ & $4.20 \pm 0.29$ \\
Globuln & $1^{\text {st }}$ day & $3.240 \pm 0.18^{\mathrm{a}}$ & $2.600 \pm 0.35^{\mathrm{b}}$ & $3,140 \pm 0.10^{\mathrm{ab}}$ & $3,38 \pm 0.10^{\mathrm{a}}$ & $3,18 \pm 0.19^{\mathrm{a}}$ \\
$(\mathrm{g} / \mathrm{dl})$ & $7^{\text {th }}$ day & $3.10 \pm 0.11^{\mathrm{ab}}$ & $2,620 \pm 0.34^{\mathrm{b}}$ & $3,120 \pm 0.07^{\mathrm{ab}}$ & $3,0 \pm 0.14^{\mathrm{ab}}$ & $3,36 \pm 0.29^{\mathrm{a}}$ \\
$\mathrm{A} / \mathrm{G}$ & $1^{\text {st }}$ day & $1.3096 \pm 0.07$ & $1.37 \pm 0.11$ & $1.2860 \pm 0.08$ & $1.192 \pm 0.04$ & $1.32 \pm 0.07$ \\
ratio & $7^{\text {th }}$ day & $1.3680 \pm 0.07$ & $1.6032 \pm 0.23$ & $1.314 \pm 0.03$ & $1.468 \pm 0.08$ & $1.3080 \pm 0.18$ \\
\hline
\end{tabular}

Means within same column carrying different superscripts are significantly different at $(\mathrm{P}<0.05)$. 
Table (5): Effect of tilmicosin (25 mg / $\mathrm{kg} \mathrm{BW)} \mathrm{and} \mathrm{or} \mathrm{/} \mathrm{thyme} \mathrm{oil} \mathrm{(200} \mathrm{ppm} \mathrm{)} \mathrm{each} \mathrm{alone} \mathrm{and} \mathrm{their}$ combination given for 5 successive days on phagocytic activity and phagocytic index in treatment of MGinfected broiler chickens.(Mean \pm S.E) $\quad n=5$.

\begin{tabular}{lllll}
\hline & \multicolumn{2}{c}{ phagocytic activity } & \multicolumn{2}{c}{ phagocytic index } \\
Groups & $1^{\text {st }}$ day & $2^{\text {nd }}$ day & $1^{\text {st }}$ day & $2^{\text {nd }}$ day \\
GP(1) & $56.2 \pm 1.1^{\mathrm{a}}$ & $60.0 \pm 1.4^{\mathrm{ab}}$ & $2.2 \pm 0.09^{\mathrm{a}}$ & $2.4 \pm 0.05^{\mathrm{b}}$ \\
$\mathrm{GP}(2)$ & $25.2 \pm 1.9^{\mathrm{c}}$ & $32.0 \pm 1.4^{\mathrm{d}}$ & $0.7 \pm 0.04^{\mathrm{c}}$ & $0.9 \pm 0.04^{\mathrm{d}}$ \\
$\mathrm{GP}(3)$ & $48.00 \pm 1.7^{\mathrm{b}}$ & $58.0 \pm 1.5^{\mathrm{b}}$ & $1.5 \pm 0.04^{\mathrm{b}}$ & $2.9 \pm 0.04^{\mathrm{a}}$ \\
$\mathrm{GP}(4)$ & $27.4 \pm 1.7^{\mathrm{c}}$ & $42.6 \pm 1.7^{\mathrm{c}}$ & $0.8 \pm 0.04^{\mathrm{c}}$ & $1.4 \pm 0.09^{\mathrm{c}}$ \\
$\mathrm{GP}(5)$ & $53.2 \pm 2.1^{\mathrm{a}}$ & $64.0 \pm 1.4^{\mathrm{a}}$ & $2.0 \pm 0.09^{\mathrm{a}}$ & $2.9 \pm 0.09^{\mathrm{a}}$ \\
\hline
\end{tabular}

Means within same column carrying different superscripts are significantly different at $(\mathrm{P}<0.05)$. 


\section{Plat (1) :}

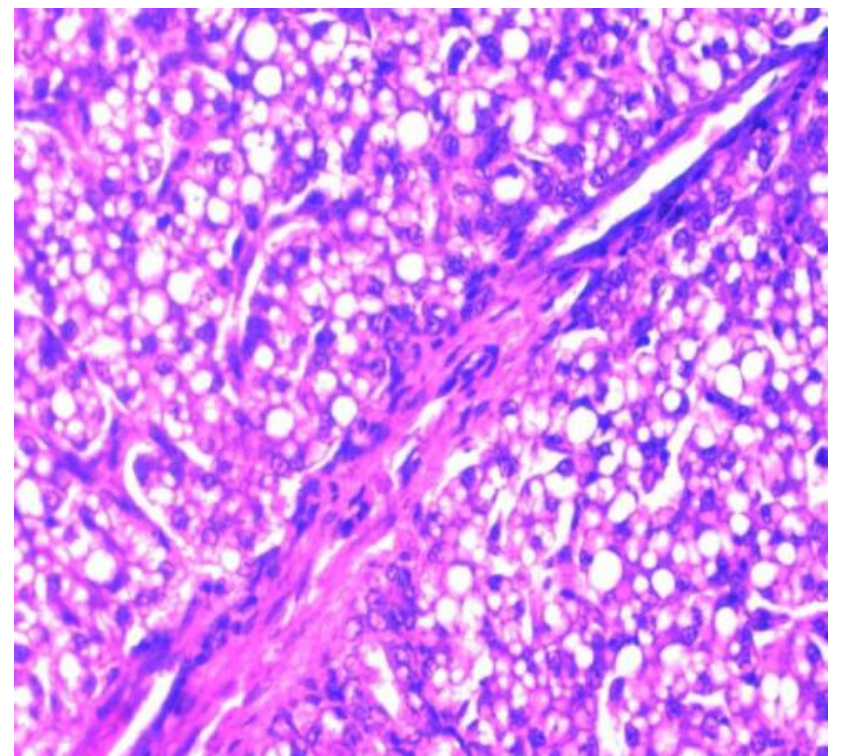

Image A

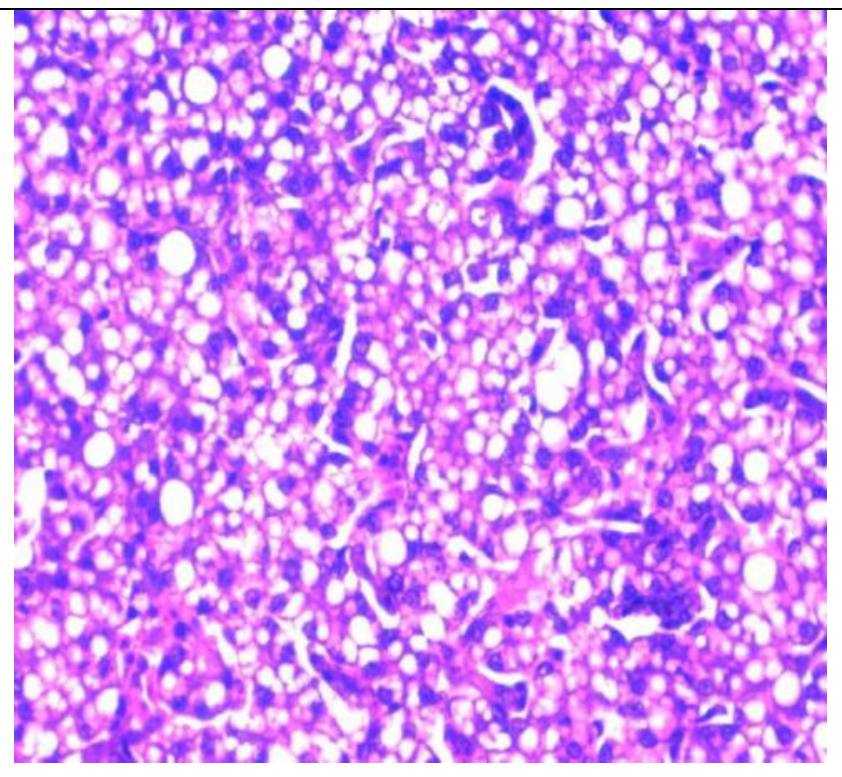

Image $\mathrm{C}$

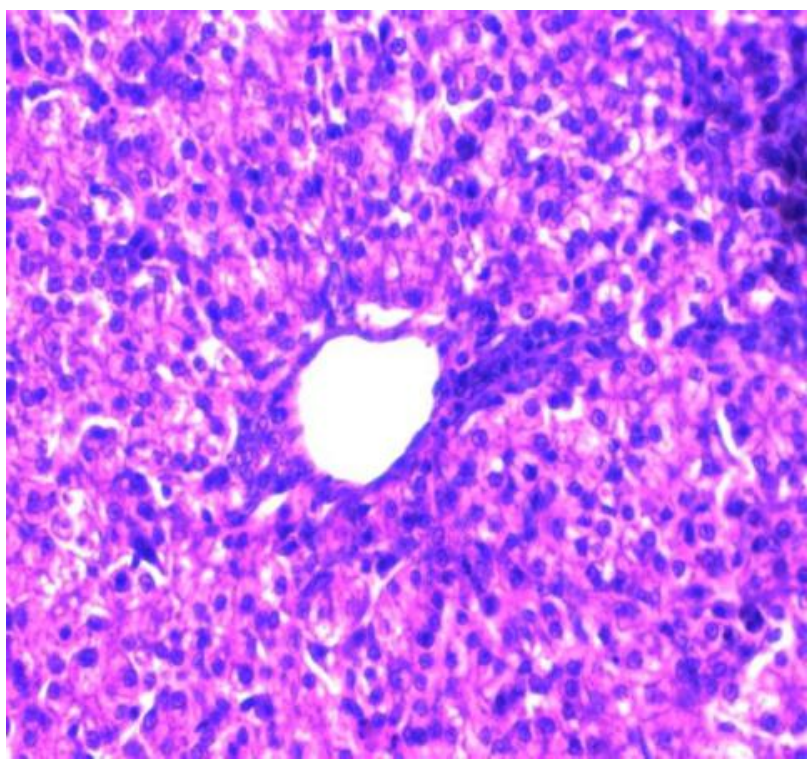

Image B

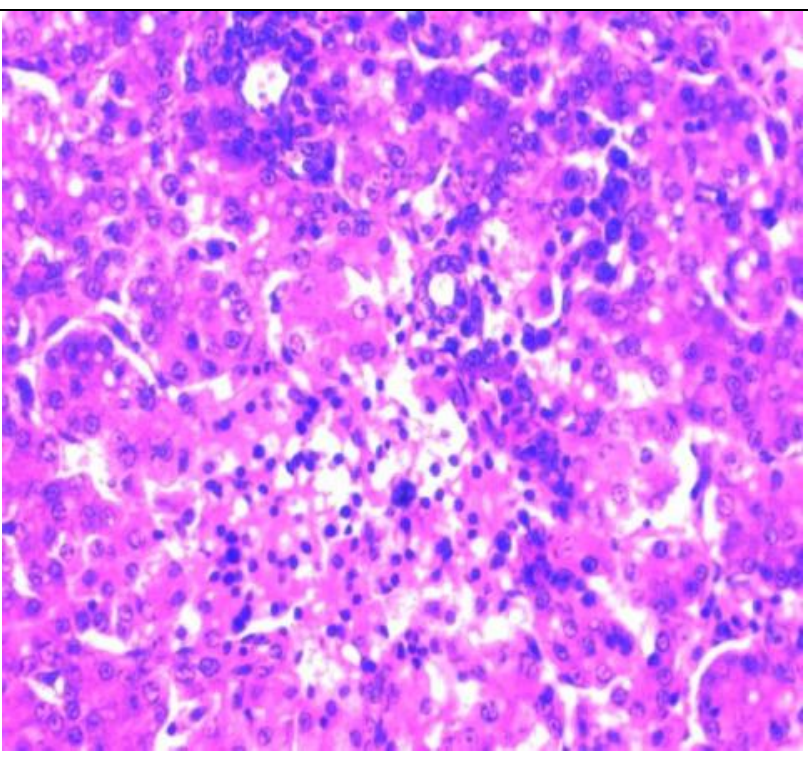

Image D

Image A : liver tissue of broiler chicken infected with mycoplasma showing severe fatty change of the lymphocytes and aggregation of inflammatory cells in the portal tract (H \& E X 200) .

Image B : liver tissue of broiler chicken infected with mycoplasma and treated with tilmicosin showing mild fatty change and presence of mild aggregation of inflammatory cells around central vein (H \& E X 200).

Image $\mathbf{C}$ : liver tissue of broiler chicken infected with mycoplasma and treated with thyme oil showing severe fatty change of lymphocytes and aggregation of inflammatory cells around central vein (H \& E X 200).

Image D : liver tissue of broiler chicken infected with mycoplasma and treated with tilmicosin and thyme oil showing return of the liver cells to its normal state and presence few scattered inflammatory cells (H \& E X 200) . 
Plat ( 2 )

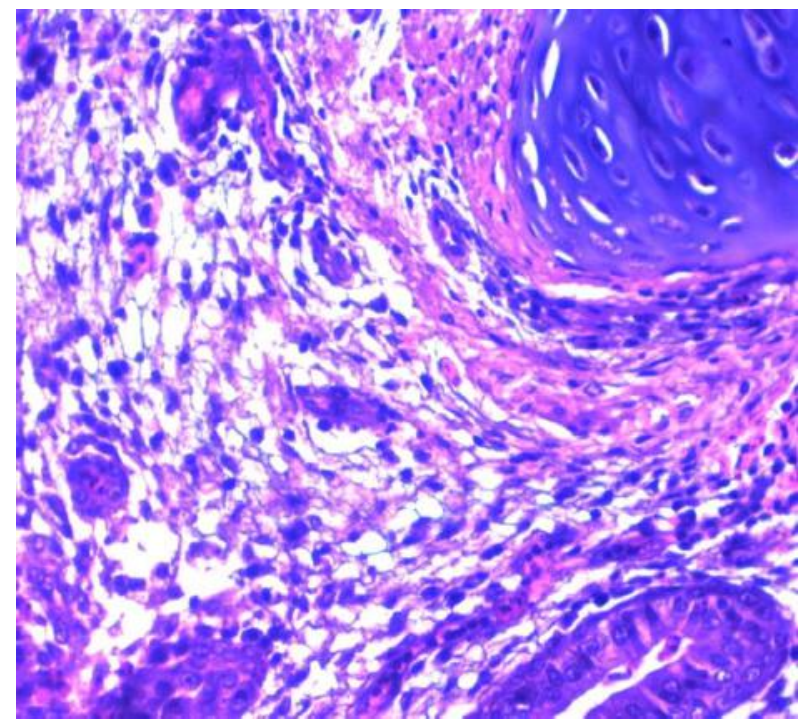

Image A

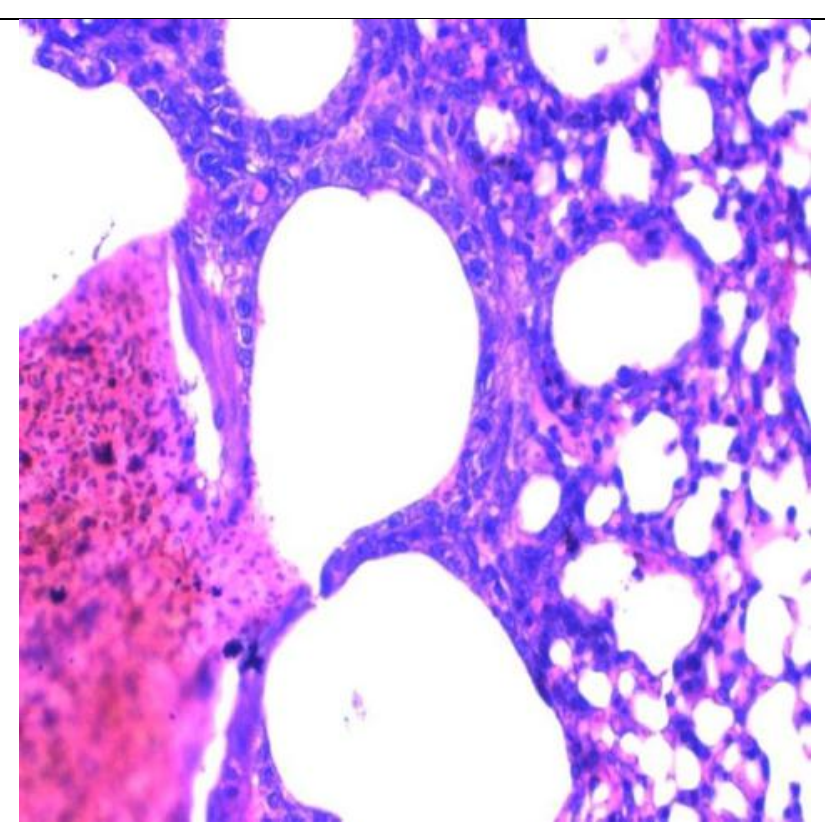

Image $\mathrm{C}$

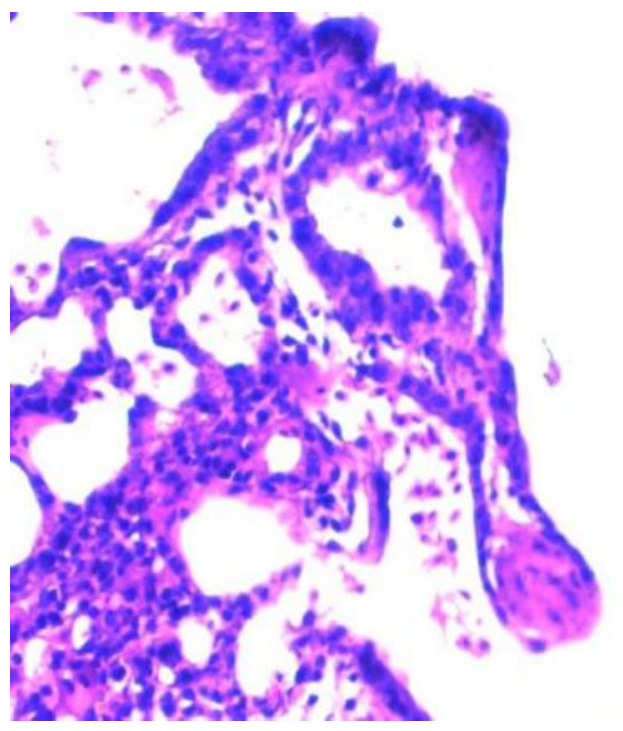

Image B

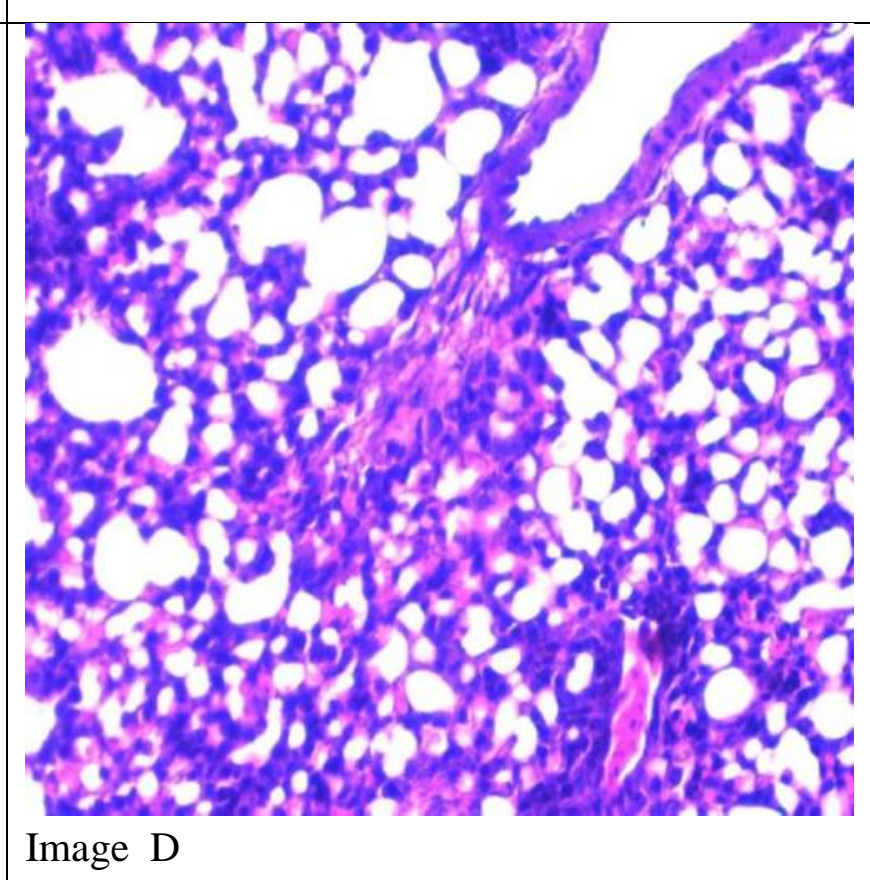

Image A : Lung tissue of broiler chicken infected with mycoplasma showing heavy aggregation of inflammatory cells and area of hemorrhage in interstitial tissue of the lung (H\&E X 200).

Image B : Lung tissue of broiler chicken infected mycoplasma and treated with telmicosin showing mild aggregation of inflammatory cells in the lung alveoli (H\&E X 200).

Image C : Lung tissue of broiler chicken infected with mycoplasma and treated with thymus showing area of hemorrhage and aggregation of inflammatory cells around the alveoli and bronchi (H \& E X 200).

Image D : Lung tissue of broiler chicken infected with mycoplasma and treated with tilmicosin and thymus showing normal lung alveoli and bronchi (H \& E X 200). 
Plat ( 3 )

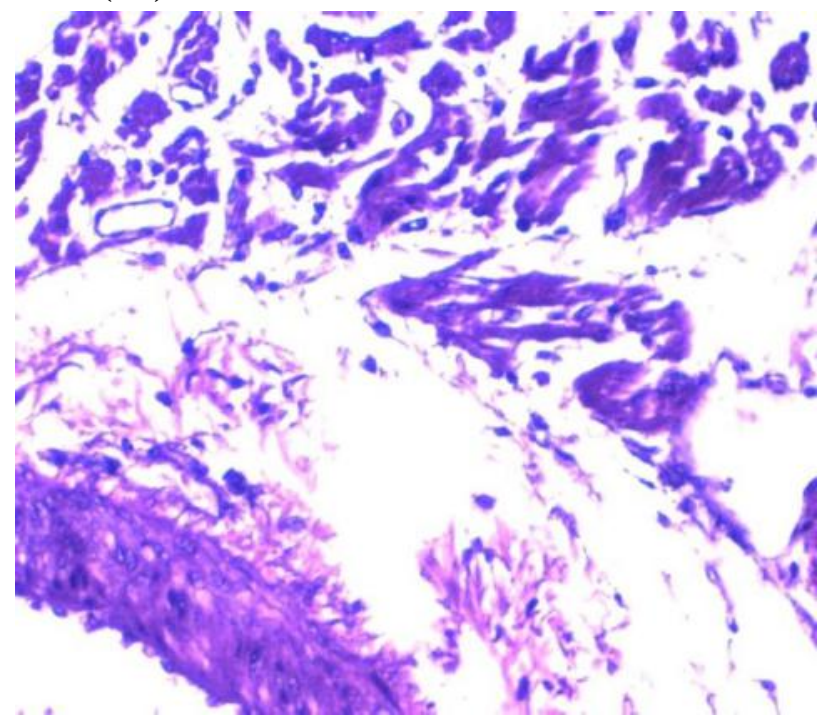

Image A

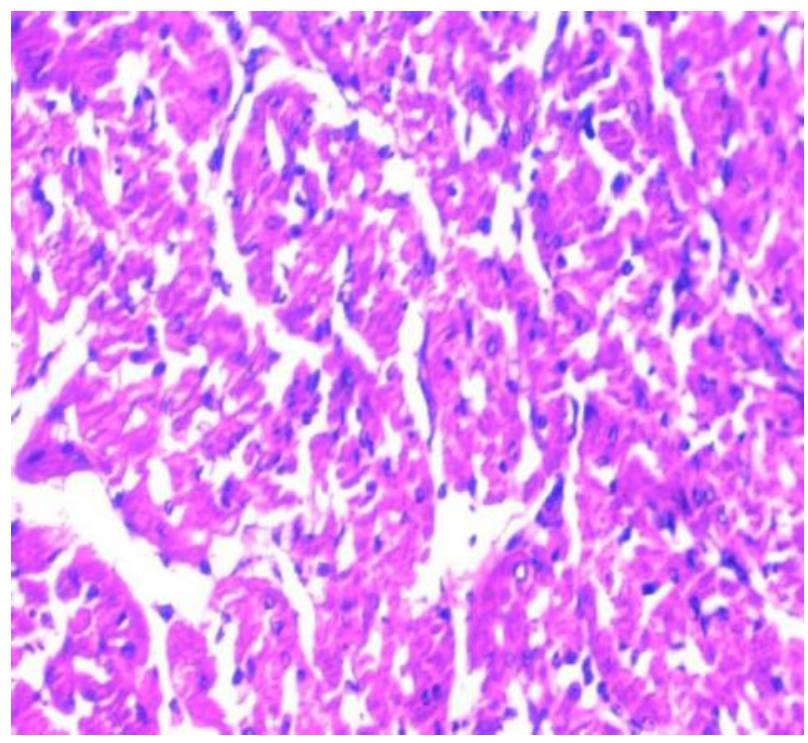

Image B

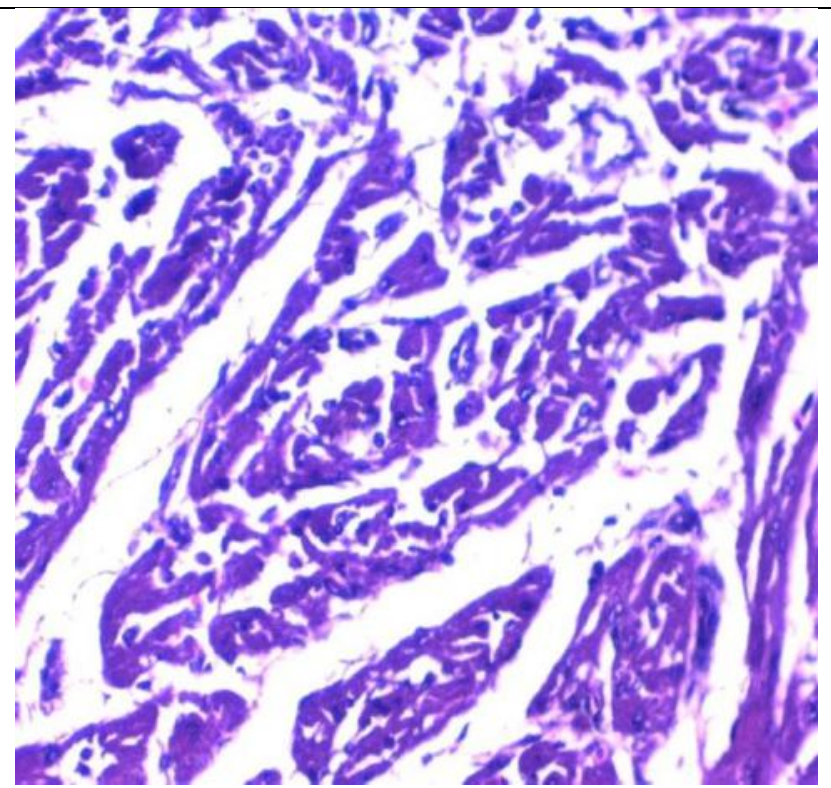

Image $\mathrm{C}$

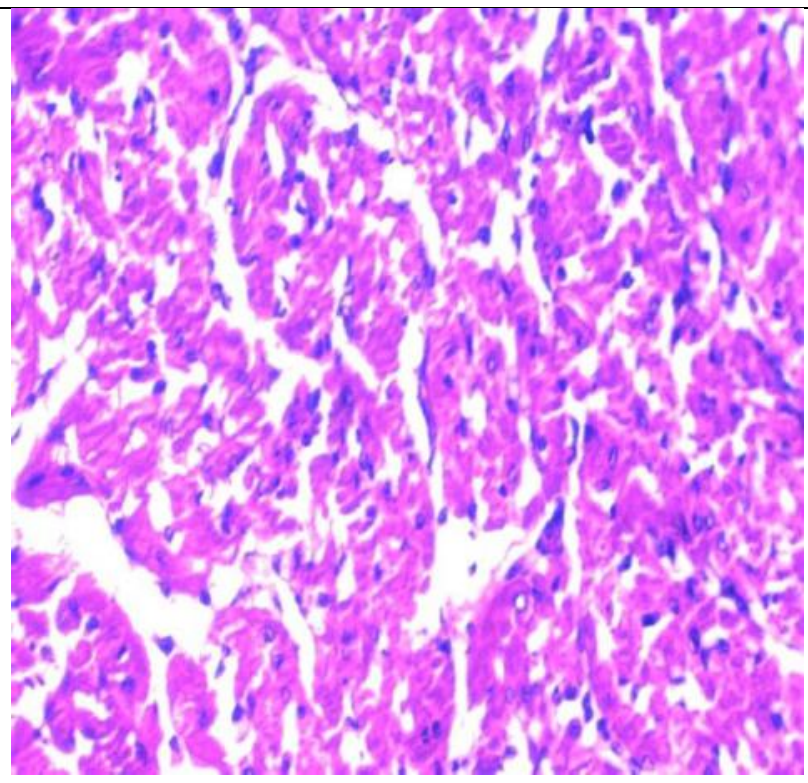

Image D

Image A : Cardiac tissue of broiler chicken infected with mycoplasma showing atrophy and necrosis of the Cardiac muscles and increase aggregation of inflammatory cells (H and E X 200).

Image B : cardiac tissue of broiler chicken infected with mycoplasma and treated with tilmicosin show regeneration of cardiac muscles and mild aggregation of different inflammatory cells $(\mathrm{H} \& \mathrm{E}$ X 200).

Image C : Cardiac tissue of broiler chicken infected with mycoplasma and treated with thymus show atrophy of the Cardiac muscles and increase aggregation of inflammatory cells(H\&EX 200). Image D : cardiac tissue of broiler chicken infected with mycoplasma and treated with tilmicosin show regeneration of cardiac muscles and mild aggregation inflammatory cells (H \& E X 20 
Plate (4)

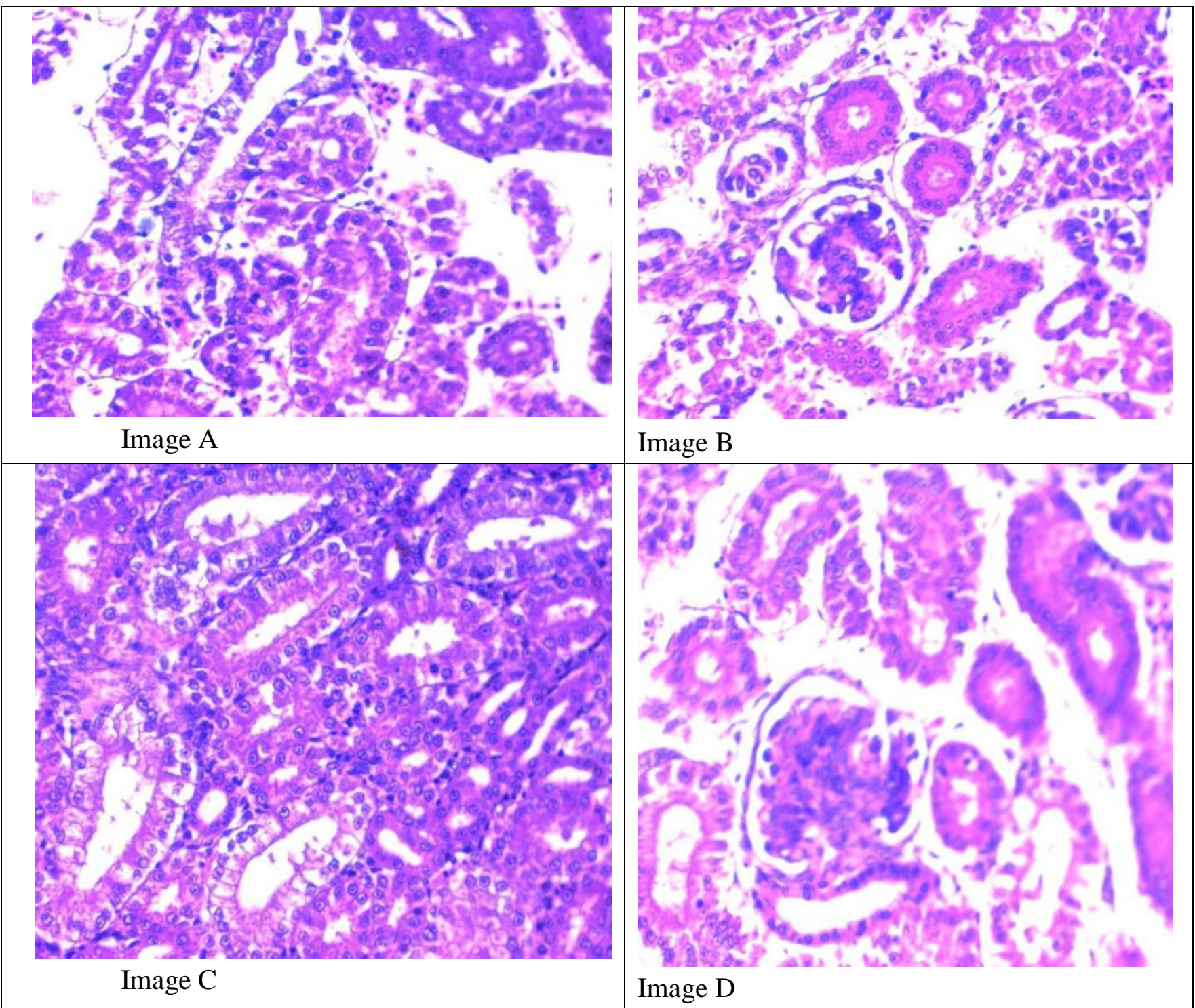

Image A: Renal tissue of broiler chicken infected with mycoplasma showing hydroipic degeneration and slaughing of renal tubular epithelial cells with aggregation of inflammatory cells in the connective tissue stroma (H \& E X 200).

Image B: Renal tissue of broiler chicken infected with mycoplasma and treated with telmicosin showing normal glomeruli and tubules with few scattered inflammatory cells (H \& E X 200).

Image C: Renal tissue of broiler chicken infected with mycoplasma and treated with thymus showing hydroipic degeneration of renal tubular epithelial cells with aggregation of inflammatory cells (H \& E X 200).

Image D: Renal tissue of broiler chicken infected with mycoplasma and treated with telmicosin and thymus showing normal glomeruli and tubules and few scattered inflammatory cells (H \& E X 200).

\section{DISCUSSION}

The clinical signs observed in infected broilers chickens were poor appetite,

depression, nasal discharge, mild conjunctivitis, sneezing, coughing, gasping, 
rales, and mortalities. Similar findings were obtained by (Jordan , 1997, Nunoya et al., 1997, Mohamed et al., 2007)

Treated infected broilers chickens with tilmicosin and thyme oil either alone or in combination showed improvements in clinical signs, mortalities and body weight. The best results were showed in broilers treated with thyme oil and tilmicosin due to the antimycoplasmal effect of tilmicosin (Abd ElSamie, 2014), the antioxidant effects of thyme oil (Placha et. al 2013 and Placha et. al 2014) and also thyme oil growth promoter effects (Saki et. al 2014). Besides, Mohamed and Mohamed (2007) and Abdel-Ghany, (2009) reported that tilmicosin is successful for treatment chickens infected with MG with reduction in clinical signs, mortalities and improved body weight gains.

Blood parameters are good indicators of physiological, pathological and nutritional status of an animal (Ganong, 1999). Our study revealed a significant increase in $\mathrm{RBCs}$ count $\mathrm{Hb}$ content and significant leukocytosis in thyme oil treated chicks, this result is compatible with that of Al-Kassie, (2009) and Hassan et al.(2004) they found that was a significant increase in $\mathrm{HB}$ and $\mathrm{RBC}$ count post using thyme. Our result is agree with Youssef et al. (2017) who reported that thyme oil induced elevation in WBC count. The protective effects of thyme oil on body cells like RBCs or the hemobiotic system may due to its protective antioxidant proprieties (Farag et al., 1989, Aeschbach et al. 1994, Cuppett and Hall, 1998 and Sylvestre et al., 2006).

Infected chicks with MG revealed leukocytopenia at $1^{\text {st }}$ and $7^{\text {th }}$ day post treatment meanwhile treatment infected chick showed improvement in leukocytic count. Our results are similar to Mohamed et. al (2007) reported who that MG is immunosuppressant agent, and AbdelSamie(2014) concluded that tilmicosin phosphate was efficient enough to control the pathogenicity of MG and thus leading to immune stats enhancement. Also Sande et al. 1985 and Khalifeh et. al, (2009) reported that tilmicosin had beneficial impacts in control the MG infection and improve cellmediated immune response. Saki et al., (2014) reported that oral administration of thyme oil at level of $2 \mathrm{~mL} / \mathrm{L}$ could ameliorate the immune response as a health status.

The results of this study showing increase in liver enzymes in $\mathrm{MG}$ infected chickens with some improvement in infected treated chickens similar to these results Mossad et. al (2017) who reported an increasing in levels of liver enzymes in MG infected broiler chickens with improvement of liver enzyme concentration post treatment with tiamulin (a macrolide antibiotic). Thyme oil treated chickens induced temporarily improvement of liver enzyme, this reflect that thyme oil did not kill MG but ameliorate the liver condition. Our results agreed with Xiaolei Zhu et al.(2014) who reported that thyme essential oil significantly decreased liver enzyme activity in broiler chickens.

Our results showed that infected chicks with MG revealed significant decrease in serum total protein, albumin and globulin. Treatment of infected broiler chickens with tilmicosin_or thyme oil improved serum protein level. The observed decrease in serum total protein, and albumin in MG-infected chicks may be due to the necrotic effect of MG on the hepatocytes which are the main site of protein synthesis or related to loses of albumin through the damaged renal tubules (Sorkar et al 2005). Moreover, the decreased serum globulin was related to the destructive effects of MG on the immune- producing cells of birds (Warner et al 1992 and Javed et al 2005).

Our results showed that Tilmicosin and thyme oil treated chickens revealed that improved serum total protein and globulin values than infected non-treated chicks 
showed improvement in serum protein values , this results due to its antimycoplasmal effect and good distribution of tilmicosine Mohamed and Mohamed (2017). These results come in compatibility with Xiaolei Zhu et. al (2014) who mentioned that dietary thyme oil in broilers chicks induce increase serum total proteins and globulins.

Our study revealed that MG infection induced elevation in creatinine and uric acid. This elevation mat be due to MG induced renal tissue damage and reduced renal excretion (Coles 1986). Also such result is in agreement with Mohamed et. al (2007) and Kempf et al (1988).

Our results displayed that phagocytic activity was lowered in infected chickens with MG this due to the immunosuppressant action of Mycoplasma on immune system. Same results were reported by Mohamed and Mohamed (2007) who noticed lower values of phagocytic activity in mycoplasma infected birds.

The observed elevation in phagocytic activity in treated broiler chickens especially chickens treated with thyme oil because thyme oil can stimulate non-specific immune system (Langhout, 2000).

Infected broiler chickens with $\mathrm{MG}$ showed gross lesion in trachea, lungs, air sacs, heart and liver Bajwa et al., (1992) and Saif et at.( 2003). Also, Our results showed serious lesions in these mentioned visceral organs.

Microscopical examination of broiler chickens infected with $\mathrm{MG}$ revealed that lungs are showing heavy aggregation of inflammatory cells and area of hemorrhage in the interstitial tissue of the lung, with congestion. Liver in broiler chickens infected with Mycoplasma gallisepticum revealed fatty change of the lymphocytes and aggregation of inflammatory cells in the portal tract, heart revealed that pericardium was thickened with atrophy and necrosis of the Cardiac muscles and increase aggregation of inflammatory cell, kidneys showed hydroipic degeneration and sloughing of renal tubular epithelial cells with aggregation of inflammatory cells in the connective tissue stroma, Same pathological lesion was reported by (Amir et. al 2011 Saif et al. 2003 and Mohamed et. al 2007). The improvement in microscopical picture in mentioned visceral organs after usage of thyme oil and tilmicosin is due to thyme oil constituents can reach plasma, gut and other edible tissues in broiler chickens such as liver and flesh (Alexander et. al, 2015). Tilmicosin Peak plasma concentration was 1.25 \pm 0.0 .09$ $\mu \mathrm{g} / \mathrm{mL}$ and achieved at 3 hours, also it has good distribution and penetration in lung, liver, kidney and muscle (Mohamed and Mohamed (2017).

\section{CONCLUSION}

It could be concluded that the concurrent use of both thyme oil and tilmicosin is a useful mean to treat and control CRD in broiler chicks. Thyme oil can be used as an assistant factor to retard CRD in broiler chicks due to its immune enhancer and growth promoter properties.

\section{REFERENCES}

Abd El-Ghany, Wafaa, A. (2009). The Invitro and In-vivo Evaluation of Tiamulin and Tilmicosin for the Treatment of Mycoplasma gallisepticum Infected Broiler Chickens International Journal of Poultry Science 8 (12): 1189-1198.

Abd El-Samie (2014) .Evaluation of tilmicosin in treatment of Mycoplasma gallisepticum infected chickens. Assiut Vet. Med. J. 60(142) 250- 259.

Abu-Basha, N; Idkaidek, A and Al-Shunnaq, A (2007), Pharmacokinetics of Tilmicosin (Provitil Powder and Pulmotil Liquid AC) Oral Formulations in Chickens, Veterinary Research Communications , 31 (4), 477-485 . 
Acamovic T. and Brooker J., (2005). Biochemistry of plant secondary metabolites and their effects in animals. Proc. Nutr. Soc. 64, 403-412.

Aeschbach, R., Löliger, J. and Aruoma, O. (1994), Antioxidant actions of thymol, carvacrol, 6-gingerol, zingerone and hydroxytyrosol. , Food Chem Toxicol. 32(1):31-36.

Alexander Haselmeyer, Jürgen Zentek , Remigius Chizzola (2015), Effects of thyme as a feed additive in broiler chickens on thymol in gut contents, blood plasma, liver and muscle, Journal of the Science of Food and Agriculture vlume95, Issue 3 , Pages 504-508

AL-Kassie A. M.(2009), Influence of two plant extracts derived from thyme and cinnamon on broiler performance. Pakistan Vet. J., 29(4), 169-173 .

Amir I, Asim A, Zafar I, Mansoor U, Habib U, Khalid S and Ishtiaq A (2011). Pathology of Mycoplasma gallisepticum in naturally Infected Broilers and its diagnosis through PCR. Int. J. Agric. Biol., 13, (4) 212-221

Anthony, T., Twin, K., Erin, M. and Michael, E. (1985): Phagocytic and killing capacities of uterine derived leukocytes from mares resistance and susceptible to chronic endometritis Am. J. Vet res. 46(9):1938-1940.

Bajwa, N.Z., M. Siddique and M.T. Javed, (1992). Pathogenesis of Escherichia coli in previously Mycoplasma gallisepticum infected layer chicks. J. Islamic Acad. Sci., 5: 123-126.

Bancroft GD and Stevens A (1996): Theory and Practice of Histopathological Techni-que.4th edition, Churchill Livingstone Edinburgh, London, Melbourne and New York.

Boyum A. (1968), isolation of mononuclear cells and granulocytes from human blood . Canadian j.Clin.Invest , $21: 77$
- 89. Wilkinson PC(1976), recognition and response in mononuclear and granular phagocytes

.Clin.Exp.Immunol.,25(3):255-366 .

Branton, S., Bearson, S., Bearson, B. and Pharr, G. (2003): Mycoplasma gallinarum infection in commercial layers and onset of fatty liver hemorrhagic syndrome. Avian Dis., 47, 2, 458-462.

Charleston, B., Aitken, I. and Reeve J. (1998). Assessment of the efficacy of tilmicosin as treatment for Mycoplasma gallisepticum infections in chickens. Avian Pathol.,27:90-95.

Coles, E. (1986): Veterinary Clinical Pathology. 4th Ed.,W.B. Saunders Company. Philadelphia, London, Toronto, Mexico, City, Sydney, Tokyo, Hong Kong.

Doumas, B., Baysee,D., Carter, R., Peters, T., Schaffer, R. (1981). Determination of serum albumin. Clin. Chem.Acta. 27:1642-1650.

Cuppett, S., and Hall, C. (1998). Antioxidant activity of Labiatae. Adv. Food Nutr. Res. 42:245-271.

Ellakany, H.; Katalin, F. and Stipkovits, L. (1997): Immunoblot examination of humoral response of chickens infected with Mycoplasma gallisepticum at various age. Comp. Immun. Microbiol. Infect. Dis. 20(4), 319-333.

Evans, R., Trites, J., and Cochrane, R. (2002). Field evaluation of tylosin in layers previously vaccinated with a live Mycoplasma gallisepticum vaccine. Avian Dis., 46:20-21.

Farag, R., BadeiF, M., Hewedi, G., and ElBaroty, S. (1989) Antioxidant activity of some spice essential oils on linoleic acid oxidation in aqueous media Journal of the American Oil Chemists Society. 66(6),792-799 . 
Ganong WF (1999). Review of Medical Physiology. 19th ed. Stanford, Connecticut, Appleton and Lange, p. 353.

Goddeeris, B., Boldvin, C., Moiyoio, O. and Morrison, W. (1986) Improved methods for purification and depletion of monocytes from bovine peripheral blood mononuclear cells . Fucnctional valuation of monocytes in response to lectins. Imm.Meth.J,89(2):165-73 .

Grant, G; Sliverman, L and Christenson, R (1987):Amino acids and proteins. In: Fund-amental of clinical chemistry $3^{\text {rd }}$ Ed., P29-45, NW Titez Philadelphia WB Saunders Comp.

Harvey, J.W. (2012): Veterinary Hematology:

A Diagnostic Guide and Color Atlas. Elsevier Saunders, Missouri.

Hassan, I., Aksar, A. and El-Shourbagy, G.(2004). Influence of some medicinal plants on performance; physiological traits of broiler. Egypt. Poult. Sci. J., 24:247-266.

Javed MA, Frasca S, Rood D, Cecchini K, Gladd M, Geary ST and Sibart LK (2005): Correlates of immune protection in chickens vaccinated with Mycoplasma gallisepticum strain GT5 following challenge with pathogenic Mycoplasma gallisepticum strain R low. Inf. Immun., 7 (9): 5410-5419.

Jordan, F.(1997): Poultry Diseases, 4th ed.. Bailliere Tindall, London.

Jordan, F. and Horrocks, B. (1996) The minimum inhibitory concentration of tilmicosin for mycoplasma gallisepticum and synoviae and a comparison of their efficacy in control of Mycoplasma gallisepticum infection in broiler chicks. Avian Diseases, 40, 326-334.

Kempf, I., Reeve L., Gesbert, F. and Guittet, M. (1997) . Efficacy of tilmicosin in the control of mycoplasma gallisepticum infection in chickens. Avian Dis. 41(4):802-807.

Kempf, I., Cacou, P. and Morin, M. (1988): Evaluation of the efficacy of kitasamycin in chickens experimentally infected with $M$ gallisepticum. Recu Med Vet.,164:53-59.

Khalifeh M. S. Amawi M.M. Abu-Basha E.A. Bani Yonis I. (2009) , Assessment of humoral and cellularmediated immune response in chickens treated with tilmicosin, florfenicol, or enrofloxacin at the time of Newcastle disease vaccination, Poult Sci (2009) 88 (10): 2118-2124.

Mohamed, E. and Mohamed, A.(2017), Pharmacokinetics, tissue residues of tilmicosin phosphate and its in vitro and in vivo evaluation for the control of Mycoplasma gallisepticum infection in broiler chickens, International Journal of Pharmacology and Toxicology, 5 (1) 11-16.

Mohamed A. Hashem, Sameh M. El-Nabtity and Hussein Saad, (2007) effect of kitasamycin on mycoplasma gallisepticum infection broilersbiochemical, immunological and pathological studies, 5th Int. Sci. Conf., Mansoura, 10-11 April 2007.

Mohamed, H. , Mohamed A., Khaled A. and Khalel I., (2013). Evaluation of antioxidant activity, total phenols and phenolic compounds in thyme, sage (Salvia officinalis L.), and marjoram (Origanum majorana L.) extracts , Industrial Crops and Products 43,Pages 27-31.

Mossad, E., Ashraf E., Mohamed A. and Mohamed M.,(2014).Tissue Residues, Hematological and Biochemical Effects of Tilmicosin in Broiler Chicken. Veterinary Medicine International, Article ID 502872, 6 pages. 
Nunoya, T., Kanai, K., Yagshashi, T. and Tajima, M. (1997): Natural case of salpingitis apparently caused by Mycoplasma gallisepticum in chickens. Avian Pathology 26: 391-393.

Placha, I., Takacova,J., Strompfova, V. and Faix, S.,(2014). Effect of thyme essential oil and selenium on intestine integrity and antioxidant status of broilers. Br Poult Sci.;55(1):105-14.

Placha,I ., Chrastinova .L., Laukova, A. Strompfova, V., Chrenkova, M., Formelova, Z. and Faix, S. (2013) Effect of thyme oil on small intestine integrity and antioxidant status, phagocytic activity and gastrointestinal microbiota in rabbits. Acta Veterinaria Hungarica, 61(2) : 197-208.

Reitman, S; Frankel, S (1957). A colorimetric method for the determination of serum glutamic oxalacetic and glutamic pyruvic transaminases.. Am. J. Clin. Path 28: 56

Rhee, K., Anderson, L., and Sams ,A. (1996). Lipid peroxidation potential of beef, chicken and pork. J. Food Sci. 61: 8-12.

Saif, Y.M.H., J. Barnes, J.R. Glisson, A.M. Fadly, L.R. McDougald and D.E. Swayne, (2003). Diseases of Poultry, 11 th edition, pp: 719-745. Iowa State University Press, Ames, Iowa.

Saki, A., Kalantar ,M and Khoramabadi V (2014) Effects of Drinking Thyme Essence (Thymus vulgaris L.) on Growth Performance, Immune Response and Intestinal Selected Bacterial Population in Broiler Chickens Poultry Science Journal, 2 (2): 113-123.

Sande , M.A. and Mandell, G.L. (1985): Antimicrobial agents, tetracycline, chloramphenicol, erythromycin and miscellaneous antibacterial agents. In: The pharmacological basis of therapeutics. Goodman Gilman A.L.S;
Rall; T.W.; Murad, F. (Eds.). Macnillan puplishing company New York, pp: 1110-1118.

Snedecor, G. and Cochran W (1994) Statistical Methods. $8^{\text {th }}$ ed. Oxford and IBH Publication India:

Stipkovits, L. and Kempf I. (1996) Mycoplasmoses in poultry. Rev. sci. tech. Off. int. Epiz., 1996, 15 (4), 14951525 .

Sylvestre, M.;Pichette, A. and Legault J. 2006 Essential oil analysis and anticancer activity of leaf essential oil of Croton flavens L. from Guadeloupe. $\mathrm{J}$ of Ethnopharmacolog , 103: 99-102.

Vamanu Emanuel, Vamanu Adrian, Niţă Sultana and Colceriu Svetlana (2011) Antioxidant and Antimicrobial Activities of Ethanol Extracts of Cynara Scolymus (Cynarae folium, Asteraceae Family). Tropical Journal of Pharmaceutical Research; 10 (6): 777783.

Warner N, Szenbrg A and Burent F (1992): The immunological role of different lymphoid organs in the chicken. Aust. J. Exp. Boil. Med. Sci., 40:373-382.

Wilkinson PC(1976), recognition and response in mononuclear and granular phagocytes .Clin.Exp.Immunol.,25(3):255-366 .

Xiaolei, Z., Wenxiao, L., Shibin, Y. and Hong C. (2014), The Effect of Different Dietary Levels of Thyme Essential Oil on Serum Biochemical Indices in Mahua Broiler Chickens, Italian Journal of Animal Science 13(3): 576-581.

Yanishlieva, N., Marinva, E, Gordn, M and Raneva, V (1999). Antioxidant activity and mechanism of action of thymol and carvacrol in two lipid systems.Food Chem 64:59-66.

Youssef, A., Ahmed, A. and Nehal, K. (2017) Thyme oil as a natural growth promoter for broiler chickens reared under hot climate Italian journal of animal science. 16(2):275-282. 